BIOORGANIC CHEMISTRY

\title{
Synthesis and evaluation of antitumor activity of some thiazolo[4,5-b]pyridines
}

\author{
T. I. Chaban, R. R. Panchuk ${ }^{1}$, O. V. Klenina, N. R. Skorokhyd ${ }^{1}$, \\ V. V. Ogurtsov, I. G. Chaban \\ Danylo Halytsky Lviv National Medical University \\ 69, Pekarska Str., Lviv, Ukraine, 79010 \\ ${ }^{1}$ Institute of Cell Biology, NAS of Ukraine \\ 14/16, Drahomanov Str., Lviv, Ukraine, 79005 \\ chabantaras@ukr.net; rpanchuk@ukr.net
}

\begin{abstract}
Aim. To synthesize a series of novel 3H-thiazolo[4,5-b]pyridine-2-ones by structural modification of the core heterocycle in its N3- and N6-positions and to evaluate their anticancer activity in vitro on several tumor cell lines. Methods. Organic synthesis, ${ }^{\prime} H-N M R$ spectroscopy, trypan blue cell viability assay. Results. A new convenient synthetic approach was developed and optimized conditions were studied for the reaction of preparation of $3 \mathrm{H}$ thiazolo[4,5-b]pyridin-2-one derivatives. 5,7-Dimethyl-3H-thiazolo[4,5-b]pyridin-2-one and 6-phenylazo-5,7dimethyl-3H-thiazolo[4,5-b]pyridin-2-one were obtained by [3+3]cyclocondensation of 4-iminothiazolidone2 with acetylacetone and $\alpha$-phenylazoacetylacetone in methanol medium in the presence of sodium methylate. They were used as starting compounds for further structural modification of the core thiazolo[4,5-b]pyridine heterocycle in its 3-and 6-positions. On the basis of in vitro cytotoxicity studies of synthesized compounds several structure-functional relationships underlying anticancer potential of 5,7-dimethyl-3H-thiazolo[4,5-b]pyridin2-one derivatives were identified. Conclusions. 3H-thiazolo[4,5-b]pyridin-2-one can be considered as a promising molecular scaffold for rational design of potential anticancer drug candidates. Introduction of phenylazo substitute at C6-position of 3H-thiazolo[4,5-b]pyridin-2-one proved to be the most efficient, as it led to 3-fold increase of its anticancer potential.
\end{abstract}

Keywords: thiazolo[4,5-b]pyridines, [3+3]cyclocondensation, structural modification, antitumor activity.

Introduction. The development of diverse strategies for the directed synthesis of potential drug candidates consists of several steps, starting from scaffold hopping towards the hit compounds identification and their further in silico rational design. Molecular scaffold-based design of 4-thiazolidine analogs is inspired by both the variety of their pharmacological actions and accessibility of chemical modification of their structure. A series of 4-thiazolidines are at different stages of clinical trials as anti-inflammatory, antitumor, antimicrobial, antiviral, cardiovascular and thrombolytic drug candidates [1].

The thiazolidine based heterocycles and their analogs fused with the pyridine ring serve as attractive tar-

(C) Institute of Molecular Biology and Genetics, NAS of Ukraine, 2012 gets for developing efficient protocols to prepare thiazolo[4,5-b]pyridine scaffolds the biological activity of which still remains poorly studied.

There is little information available about the biological activity of thiazolo[4,5-b] pyridines. For example, some of their derivatives were described as useful antimicrobial agents effective against a variety of human and veterinary pathogens including Gram-positive and Gram-negative aerobic and anaerobic bacteria, as well as mycobacteria [2]. Thiazolo[4,5- $b$ ]pyridines also show potent inhibitory activities for $\mathrm{A} \beta 42$ fibrillization at a micromolar level for Alzheimer's disease treatment [3], some of them are $\mathrm{H} 3$ receptor antagonists [4], others were revealed to activate the GK enzyme in vitro and significantly reduce glucose levels [5]. Some thiazolo [4,5-b]pyridine analogues are potent antistaphylococ- 
cal compounds with suboptimal drug-like properties [6]. They act as inhibitors of the bacterial cell-division protein, FtsZ. Several compounds among these substances were found to possess fungicidal action [7] or act as antagonists of metabotropic glutamate receptors 5 (mGluR5) [8], as well as epidermal growth factor receptors [9] and a number of other enzymes [10, 11].

However, the information on antitumor activity of the mentioned bicycle derivatives of 4-thiazolidones is still missing. Up to now just a few compounds of such chemical structure have been tested against some human tumor cell lines in vitro $[1,12]$. Several studies point out that 4-thiazolidone based bicyclic analogues, in particular pyrazole and isoxazole derivatives, can act as inhibitors of HSP90, an ATP-dependent molecular chaperon [12].

In normal cells HSP90 is involved in protein folding, but in cancer cells it can stabilize oncoproteins v-Src, $\mathrm{Bcr} / \mathrm{Abl}$ and mutant products of $p 53$ gene, thus possessing strong anti-apoptotic activity [13]. Several HSP90 inhibitors, such as geldanamycin, have already shown some promising effects in clinical trials [14], but search for other small molecule inhibitors of HSP90 still remains an active area of cancer research.

Tyrosine Kinases (TK) are other possible anticancer targets for 4-thiazolidone derivatives. TK play a crucial role in the action of epidermal growth factor receptor (EGFR), and mutation of the ATP-binding site of EGFR is closely associated with TK activity, being one of the main reasons of cell malignization by disrupting the formation of tumorigenic signals. That's why the development of TK inhibitors is suggested as one of the most perspective strategies for cancer treatment, and some of them, such as trastuzumab (Hercep$\operatorname{tin}^{\circledR}$ ), gefitinib, imatinib have been already widely used in cancer treatment. Several five-membered heterocycle derivatives and fused heterocycle analogs were also found to possess the TK enzymes inhibitory activity and now are at different phases of clinical trials [15].

Based on these data, the main aim of current work was the development of novel innovative approaches for organic synthesis of thiazolo[4,5- $b]$ pyridine derivatives with an eye towards the discovery of isosteric fused ring compounds with the nitrogen heteroatom as a potential atom interacting with the anticancer targets mentioned above.
Materials and methods. Synthetic routine for the novel compounds preparation was carried out according to common approaches used for the potential drug candidates rational design with proper «Merck» (Germany) chemicals implementation.

The structures of all synthesized compounds were established on the basis of quantitative elemental analysis and spectral ${ }^{1} \mathrm{H}-\mathrm{NMR}$ data ( $«$ Varian Mercury VX$400 », \mathrm{DMSO}^{-} \mathrm{d}_{6}$ was used as a solvent, tetramethylsilane as a standard).

Murine leukemia cells of L1210 line were obtained from the cell culture collection of R. E. Kavetsky Institute of Experimental Pathology, Oncology and Radiobiology, NAS of Ukraine, human breast adenocarcinoma cells of MDA-MD-231 lines were obtained from the cell culture collection of Ludwig Institute for Cancer Research (Sweden), and human melanoma cells of SKMEL-28 line were obtained from the cell culture collection of Nencki Institute of Experimental Biology PAN (Poland). Cells were cultured in DMEM medium supplemented with $10 \%$ fetal calf serum ( «Sigma Chemical Co.», USA), $50 \mu \mathrm{g} / \mathrm{ml}$ streptomycin («Sigma Chemi cal Co.»), 50 units/ml penicillin («Sigma Chemical Co.») in $5 \% \mathrm{CO}_{2}$-containing humidified atmosphere at $37{ }^{\circ} \mathrm{C}$.

For experiments, cells were seeded into 24-well tissue culture plates («Greiner Bio-one», Germany). A cytotoxic effect of antitumor drugs was studied under the Evolution 300 Trino microscope («Delta Optical», Poland) after cell staining with trypan blue dye $(0.1 \%)$ [16].

Experiments were performed in triplicate and repeated 3 times. Significance of the difference in a typical experiment was assessed by Student's $t$-test. The level of significance was set at 0.05 .

Results and discussion. In our previous report we have proposed a convenient method of 5,7-dimethyl$3 H$-thiazolo[4,5-b]pyridin-2-one preparation. The method of thiazolo[4,5-b]pyridine scaffold construction is based on [3+3] cyclocondensation of 4-iminothiazolidone- 2 on account of its N,C-binucleophilic properties with dielectrophilic reagents like acetylacetone forming 5,7-dimethyl-3 $H$-thiazolo[4,5-b]pyridin-2-one (1) [17]. We discovered that a high yield of the product in the developed protocol can be achieved by keeping the reagents mixture in methanol in the presence of sodium methylate over 5 days. 


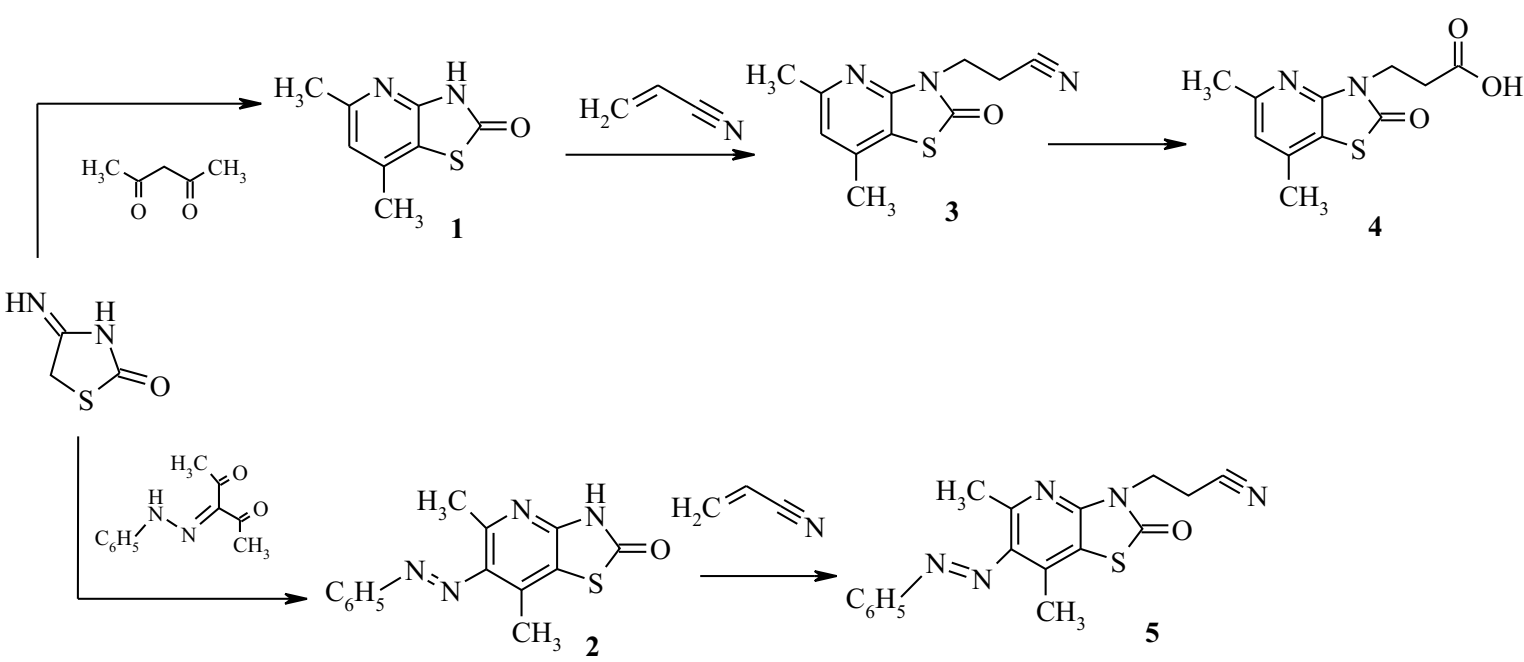

Fig. 1. Synthesis of 5,7-dimethyl-3H-thiazolo[4,5-b]pyridin-2-one (1), 6-phenylazo-5,7-dimethyl-3H-thiazolo[4,5-b]pyridin-2-one (2), the products of their cyanoethylation $(\mathbf{3}, \mathbf{5})$ and hydrolysis $(4)$ reactions

Further structural modification of thiazolo[4,5-b]pyridine scaffold in its N3 and C6 positions was investigated resulting in the preparation of its novel derivatives.

The optimized conditions were used to obtain 6phenylazo-5,7-dimethyl-3 $H$-thiazolo[4,5-b]pyridin-2one (2) by involving $\alpha$-phenylazoacetylacetone into the reaction.

Taking advantage of a good hydrogen atom mobility in NH group of the compound $1 \mathrm{~N} 3$-position allowed us to carry out its cyanoethylation which led us to designing 3-(5,7-dimethyl-2-oxo-thiazolo[4,5-b]pyridine-3-yl)-propionitrile (3) further utilized by hydrolysis for [the] 3-(5,7-dimethyl-2-oxo-thiazolo[4,5- $b$ ] pyridine-3-yl)-propionic acid (4) preparation.

3-(5,7-dimethyl-6-phenylazo-2-oxo-thiazolo[4,5-b] pyridine-3-yl)-propionitrile (5) was similarly obtained in a good yield by involving the compound $\mathbf{2}$ into cyanoethylation reaction under the same conditions as outlined in the Fig. 1.

The acidic character of the proton in the core heterocycle N3-position of compounds $\mathbf{1}$ and $\mathbf{2}$ promotes tendency of these compounds to transform into corresponding potassium salts under their treatment with potassium hydroxide. The obtained salts possess nucleophilic properties and can be involved into reactions with electrophilic reagents in mild conditions. Thus the potassium salt of 5,7-dimethyl-3H-thiazolo[4,5-b]pyridin-2-one and the same salt of 6-phenylazo-5,7-dimethyl-3H-thiazolo[4,5-b]pyridin-2-one (6) were alkylated with monochloracetic acid ethyl ester.
The next step of our strategy was the utilization of the products in the hydrazinolysis reaction with the respective hydrazides preparation like 5,7-dimethyl- $3 \mathrm{H}$ thiazolo[4,5-b]pyridin-2-one hydrazide (7). In the same way the compound $\mathbf{2}$ hydrazide is easily available while its further utilization in condensation with heterocyclic aldehyde reaction led us to the compound $\mathbf{8}$ formation. Using 3-bromopropene-1 as an alkylation agent for the compound 7 treatment allows us to get compound 9 (Fig. 2).

The reduction decoupling reaction of 5,7-dimethyl-6-phenylazo-3 $H$-thiazolo[4,5-b]pyridine-2-one (2) was studied in order to obtain 6-amine-5,7-dimethyl$3 H$-thiazolo[4,5- $b]$ pyridine-2-one as a reagent for thiazolo[4,5- $b]$ pyridines C6-position transformations. A high yield of the targeted compound 10 was found to occur in acetic acid-pyridine medium, zinc powder being used as a reduction agent. The amine group presence in its C6-position allows transforming it into appropriate 6-acetylaminoderivative (11). Dioxane was found to be the most suitable medium for the reaction of compound 10 with acetic acids chloroanhydride. The product of the compound 10 acylation with chloroacetylchloride made it possible to design 6-sulfanylacetamidederivative of the core bicycle (12) by treatment it with the appropriate thiol (Fig. 3).

We studied a cytotoxic effect of $\mathbf{1 2}$ synthesized compounds in vitro on murine leukemia cells of L1210 line, human breast adenocarcinoma cells of MDA-MD-231 line and human melanoma cells of SK-MEL-28 line 
<smiles>CCOC(=O)Cn1c(=O)sc2c(C)cc(C)nc21</smiles>

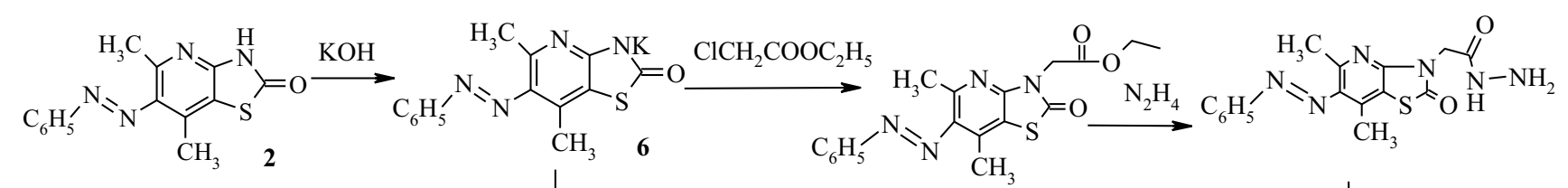

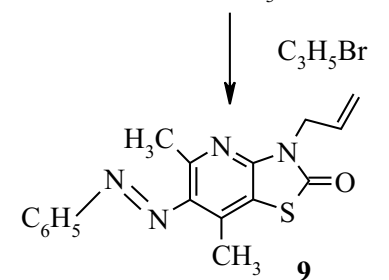<smiles>Cc1nc2c(c(C)c1/N=N/c1ccccc1)SC2=O</smiles>

Fig. 2. Synthesis of 5,7-dimethyl-3H-thiazolo[4,5-b]pyridin-2-one and 6-phenylazo-5,7-dimethyl-3H-thiazolo[4,5-b]pyridin-2-one potassium salts and their structural modifications in 3-position<smiles>CC(=O)Nc1c(C)nc2[nH]c(=O)sc2c1C</smiles>

Fig. 3. Structural modification products of 6-phenylazo-5,7-dimethyl-3H-thiazolo[4,5-b]pyridin-2-one in its 6-position

(Fig. 4, $a-c$ ). For convenience these compounds were numerated as $\mathbf{T}-\mathbf{1}-\mathbf{T}-\mathbf{1 2}$.

The core compound T-1 (5,7-dimethyl-3H-thiazolo[4,5-b]pyridin-2-one) demonstrated the weakest cytotoxic effect on all three cell lines (growth inhibition of L1210 cells only by $25 \%$ compared to control, MDAMD-231 cells by $29 \%$ and SK-MEL-28 cells only by $13 \%$ at highest concentration $100 \mu \mathrm{M})$. However, the addition of phenylazo fragment to C6-position of 5,7dimethyl-3H-thiazolo[4,5-b]pyridin-2-one molecule significantly (2-4 times) enhanced the anticancer potential of core scaffold. It was revealed that resulting T-2 inhibited the growth of L1210 cell by $65 \%$, MDAMD-231 cells by $82 \%$ and SK-MEL-28 cells by $72 \%$ at $100 \mu \mathrm{M}$ concentration. The conjugation of beta-cyanoethyl group at N3-position of core scaffold also boos- ted its anticancer activity, but to much lower extent when compared to C6-subsituted compound T-2 (37\% growth inhibition of L1210 cells, $64 \%$ inhibition of MDA-MD-231 and $66 \%$ inhibition of SK-MEL-28 cells).

However, the hydrolysis of compound $\mathbf{T}-\mathbf{3}$ side chain weakened its anticancer potential - we observed $18 \%$ inhibition of L1210 cells, while for carcinoma cells no statistically significant differences between T-3 and T-4 were found - $60 \%$ inhibition of MDAMD-231 cells (compared to $64 \%$ in case of $\mathbf{T}-3$ ) and $56 \%$ inhibition of SK-MEL-28 cells (compared to $66 \%$ in case of T-3). Thus, the terminal cyano group at $\mathrm{N} 3$-position of 5,7-dimethyl-3H-thiazolo[4,5- $b$ ]pyridin2-one derivatives seems to play some role in their antileukemic activities. 

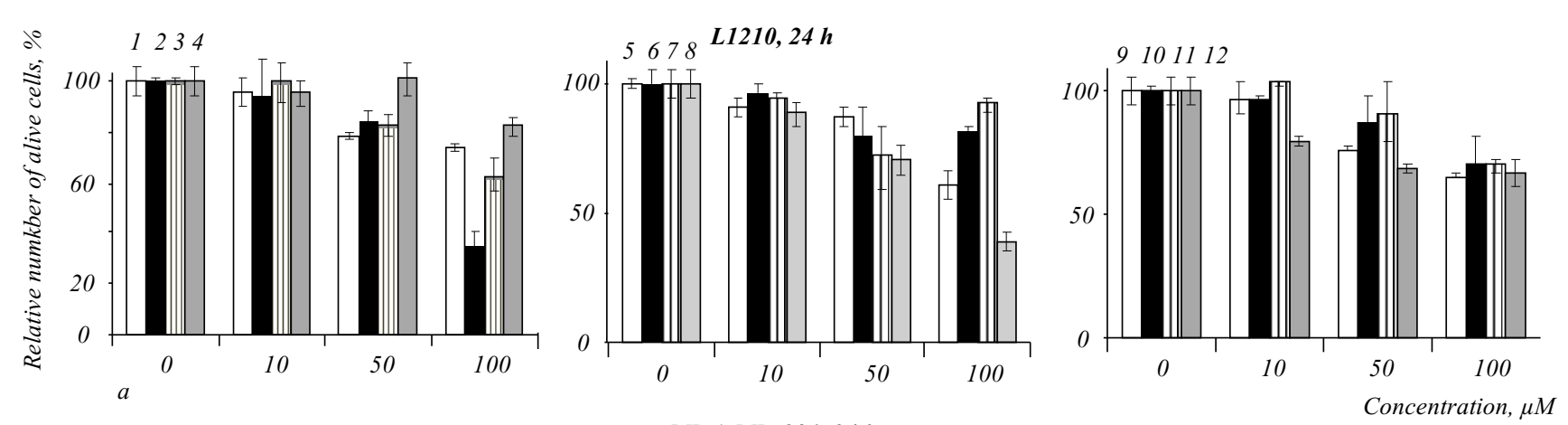

$M D A-M D-231,24 \mathrm{~h}$
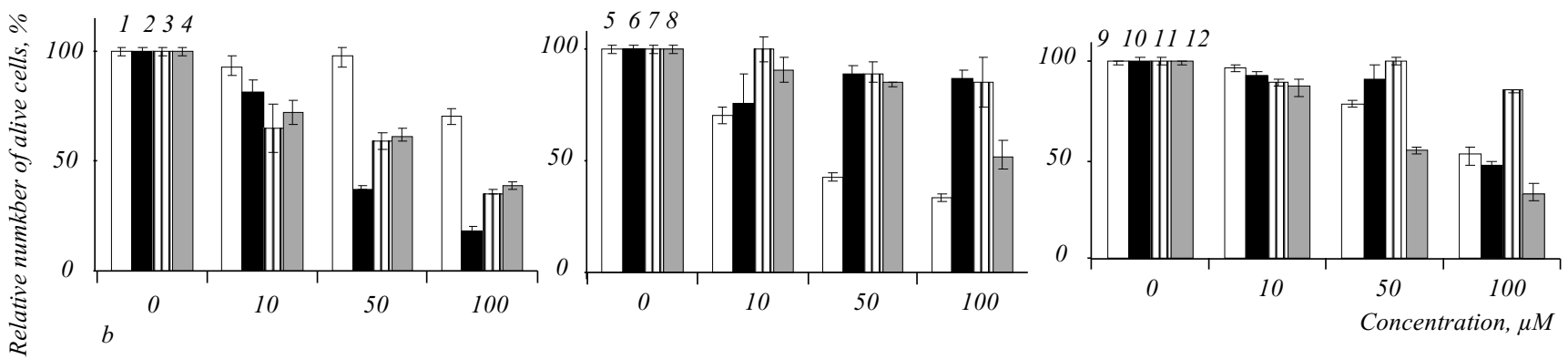

$S K-M E L-28,24 \mathrm{~h}$
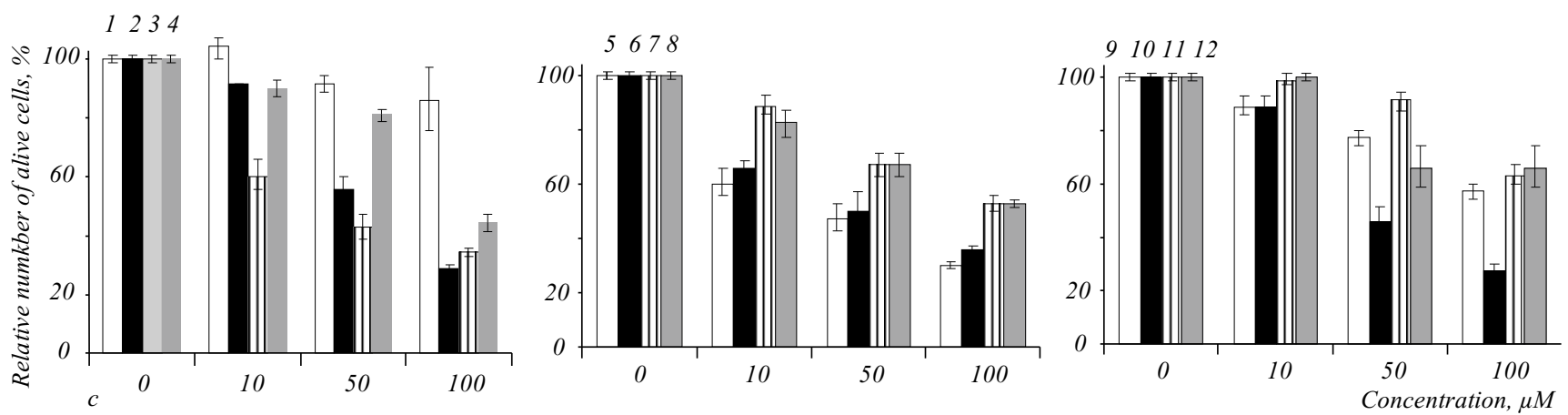

Fig. 4. Comparison of cytotoxic activity of 5,7-dimethyl-3H-thiazolo [4,5-b]pyridin-2-one derivatives in murine L1210 leukemia cells $(a)$, in human breast adenocarcinoma cells of MDA-MD-231 line $(b)$ and human melanoma cells of SK- MEL-28 line $(c)$

The conjugation of both phenylazo fragment to C6position and beta-cyanoethyl group to N3-position of core compound T-1 did not give any cumulative effect cytotoxic activity of T-5 on L1210 leukemia cells was practically the same as of T-3 and weaker than that of T-2 (39\% of growth inhibition at $100 \mu \mathrm{M}$ concentration of $\mathbf{T}-\mathbf{5}$ compared to $37 \%$ by $\mathbf{T}-\mathbf{3}$ and $65 \%$ by T-2). T-5 demonstrated a bit stronger effect on carcinoma cells of MDA-MD-231 line, than on leukemia cells ( $66 \%$ of growth inhibition compared to $64 \%$ by T-3), and the same was true for SK-MEL-28 cells (70\% of growth inhibition compared to $66 \%$ by T-3). Thus, one can see that beta-cyanoethyl group inhibits the ac- tivity of phenylazo fragment in «hybrid» molecule T-5, which suggests usage of other substitution groups at N3position of T-1 for enhancement of its activity.

Taking into consideration that $\mathbf{T}-2$ possesses relatively high anticancer activity, but is insoluble in water, we synthesized its potassium salt. However, such procedure led to almost complete loss of anticancer activity of water-soluble T-6 compound (growth inhibition of L1210 cells by only $19 \%$ at $100 \mu \mathrm{M}$ concentration compared to $65 \%$ inhibition by T-2, $12 \%$ of MDAMD-231 cells compared to $82 \%$ by T-2). Only melanoma cells of SK-MEL-28 line remained sensitive to T-6 (64 \% growth inhibition compared to $72 \%$ in case 
of T-2). This suggests specificity of the action of potassium salt of 5,7-dimethyl-6-[phenylazo]-3 $H$-thiazolo [4,5-b]pyridin-2-one (T-6) towards melanoma cells, which can be of high importance when moving to in vivo studies on experimental animals.

The next step of our study was further optimization of the core T-1 scaffold by obtaining hydrazide of this compound, named T-7 (2-(5,7-dimethyl-2-oxo-3a,4dihydrothiazolo[4,5- $b]$ pyridin-3-yl) acetohydrazide). Interestingly, T-7 demonstrated a weaker cytotoxic effect towards leukemia and carcinoma cells compared to the parental compound T-1 (8\% inhibition of L1210 cells compared to $25 \%$ by T-1 and $14 \%$ of growth inhibition of MDA-MD-231 cells compared to $29 \%$ by T-1). However, SK-MEL-28 cells were more sensitive to T-7 action compared to T-1 (47\% of growth inhibition compared to $13 \%$ by T-1). Thus, the hydrazide group in N3-position of 5,7-dimethyl-3H-thiazolo [4, $5-b]$ pyridin-2-one is responsible for higher affinity of the $\mathbf{T}-\mathbf{7}$ compound to melanoma cells.

For further evaluation of influence of other N3-position substitutes in the T-2 molecule (5,7-dimethyl-6[phenylazo]-3H-thiazolo[4,5-b]pyridin-2-one) aldehyde was conjugated to hydrazide of T-2 involving foursteps synthetic strategy. In contrast to the T-6 and T-7 compounds, which demonstrated higher affinity to melanoma cells, T-8 was more specific to leukemia cells its cytotoxic effect was the same as of T-2 (61\% of growth inhibition compared to $65 \%$ by T-2), while carcinoma and melanoma cells were significantly more resistant to the T-8 action compared to T-2 (47\% of MDA-MD-231 cells compared to $82 \%$ in case of T-2 and $48 \%$ on SK-MEL-28 cells compared to $72 \%$ in case of T-2). In conclusion, conjugation with aldehyde has not given any significant anticancer effect to T-2, which suggests that for preservation of the highest anticancer activity of T-2 scaffold (5,7-dimethyl-6-[phenylazo]-3 $H$-thiazolo[4,5-b]pyridin-2-one) no substitutes should be placed at N3-position.

Almost identical results were observed when a propionic group was conjugated to N3-position of T-2 (5, 7-dimethyl-6-[phenylazo]-3H-thiazolo[4,5-b]pyridin2-one). The resulting compound T-9 was weaker than T-2 in all three tested cell lines (35\% growth inhibition of L1210 cells compared to $65 \%$ by T-2, $47 \%$ of MDA-MD-231 cells compared to $82 \%$ by T-2 and
$43 \%$ of SK-MEL-28 cells compared to $72 \%$ by T-2). These results give an additional proof that no substitutes should be placed at N3-position for preservation of the highest anticancer activity of T-2 scaffold .

The next part of the work was dedicated to studying the influence of different substitutes in C6-position of T-1 core scaffold. At the first step phenylazo fragment was reduced to amino group, and the resulting $\mathbf{T}$ $\mathbf{1 0}$ compound completely preserved its anti-melanoma cytotoxic effect $(72,5 \%$ growth inhibition of SKMEL-28 cells compared to $72 \%$ by T-2), while its anticarcinoma effect (52\% of growth inhibition of MDAMD-231 cells compared to $82 \%$ by T-2) and antileukemia activity (29\% of growth inhibition compared to $65 \%$ by T-2) were significantly weaker than those of parental compound. Thus, the exchange of phenylazo group at C6-position for amino group somehow decreases the affinity of 5,7-dimethyl-3H-thiazolo [4,5-b] pyridin-2-one scaffold to leukemia cells. A similar phenomenon was observed when cyano terminal motif in T-3 was hydrolyzed to acid in T-4, as mentioned before.

The acylation of amino group at C6-position of T10 scaffold led to further decrease in its cytotoxic activity - the resulting compound $\mathbf{T}-\mathbf{1 1}$ was weaker than its predecessor in carcinoma and melanoma cells (14\% growth inhibition of MDA-MD-231 cells compared to $52 \%$ by T-10 and only $37 \%$ inhibition of SK-MEL-28 melanoma cells compared to $72.5 \%$ by T-10), while sensitivity of L1210 leukemia cells remained the same (30\% growth inhibition of L1210 leukemia cells compared to $29 \%$ in case of $\mathbf{T}-\mathbf{1 0}$ ).

Under the interaction of a product of acylation of aminogroup of $\mathbf{T}-\mathbf{1 0}$ by chloroacetylchloride with one of thiols, the T-12 compound was prepared. Interestingly, we observed a slight increase in anti-carcinoma effect of T-12 on MDA-MD-231 cells (66 \% growth inhibition compared to $52 \%$ effect of T-10), while its anti-leukemia action remained the same as of the parental compound (34\% growth inhibition of L1210 cells compared to $29 \%$ effect of $\mathbf{T}-10)$. In contrast to these data, SK-MEL-28 melanoma cells demonstrated decreased sensitivity to T-12 (34 \% growth inhibition compared to $72.5 \%$ by $\mathbf{T}-10$ ). Thus, further steric modifications decrease the anticancer potential of the aminogroup at C6-position of the core scaffold and thus are not effective. 
According to these results, several principal suggestions could be derived. Despite the introduction of various substitutes into the 5,7-dimethyl-3H-thiazolo[4, 5-b]pyridin-2-one core molecule, we did not succeed in significant enhancement of their anticancer activity. The average cytotoxic activity of the most potent compound with anticancer activity T-2 (6-phenylazo-5,7dimethyl-3H-thiazolo[4,5-b]pyridin-2-one) towards three cell lines was only $50 \mu \mathrm{M}$, which is still 10 times more than that of some clinically used anticancer drugs. Thus, further modifications in the structure of $6 \mathrm{~N}$-derivatives of 5,7-dimethyl-3H-thiazolo[4,5-b]pyridin-2one should be done in order to enhance its anticancer potential, as well as to perform in-depth studies of its potential targets in tumour cells. Previously we reported that conjugation of various side groups to 4-thiazolidone core could lead to the induction of different cell death pathways by such compounds [18]. However, in that case the chemical structure of substitutes had a little effect on the selectivity of action of these 4-thiazolidones toward leukemia and carcinoma cells. Here, one can see completely different situation, when exchange of a single atom can lead to complete loss of the compound activity towards specific cell line (e. g., leukemia, carcinoma, melanoma). Such data indicate a distinctive mechanism of action of thiazolo[4,5- $b]$ pyridine derivatives compared to the previously studied 4thiazolidones.

Conclusions. A few structure-functional relationships determining the anticancer potential of the 5,7-dimethyl-3H-thiazolo[4,5- $b]$ pyridin-2-one derivatives could be drawn on a basis of the data obtained. The amino group at C6-position of core scaffold seems to be important for anti-melanoma activity of the resulting compound, while the phenylazo group at the same position is responsible for a wider spectrum of cytotoxic activities. The biggest anticancer effect was observed under conjugation of the phenylazo group to C6-position of 5,7-dimethyl-3H-thiazolo[4,5-b]pyridin-2-one. None of used substitutes at N3-position alone had any significant effect which could be compared to that of the phenylazo group at C6-position. Thus, for further enhancement of the cytotoxic activity of T-2, the additional arylazo substitutes should be introduced into C6position of this lead compound. Such experiments are in progress.
T. I. Чабан, Р. Р. Панчук, О. В. Кленіна, Н. Р. Скорохід,

В. В. Огуриов, I. Г. Чабан

Синтез та вивчення протипухлинної активності деяких тіазоло[4,5-b] піридинів

\section{Резюме}

Мета. Синтезувати серію нових похідних 3Н-тіазоло [4, 5-b] піридин-2-ону, модифікуючи структуру базового гетероциклу за 3-м $i$ 6-м положеннями. Дослідити протипухлинну активність одержаних сполук іn vitro на деяких лініях злоякісних клітин ссавців. Методи. Органічний синтез, ПМР-спектроскопія, визначення життєздатності клітин за їхнім забарвленням трипановим синім. Результати. Запропоновано зручний синтетичний підхід $i$ знайдено оптимальні умови для проведення реакиій отримання 3Н-тіазоло[4,5-b]піридин-2-онів. Реакиією [3 + 3] ичиклоконденсаиії 4-іміно-2-тіазолідону з ацетилацетоном $i \alpha$-фенілазоацетилаиетоном у середовищі метанолу за присутності метилату натрію одержано 5,7-диметил-3Н-тіазоло [4,5-b]піридин-2-он і 6-фенілазо-5,7-диметил-3Н-тіазоло[4,5-b]піридин-2-он, які використано як вихідні речовини для майбутньої структурної модифікації базового тіазоло[4,5-b]піридинового гетероциклу за 3-м $i$ 6-м положеннями. Введенням вихідних сполук у реакції цііаноетилювання з подальшим гідролізом отриманого продукту алкілування, яке відбувається через стадію одержання відповідних калійних солей, з наступним гідразинолізом продуктів, а також у реакцію відновлювального розщеплення з дальшим ацилюванням продуктів одержано серію нових похідних 3Н-тіазоло[4,5-b]піридин2-ону. Висновки. Тіазоло[4,5-b]піридин-2-он можна вважати перспективним молекулярним каркасом, що дозволяє застосовувати зазначену конденсовану систему для раціонального дизайну потенційних лікарських засобів з широким спектром різних видів біологічної активності. Найефективнішим виявилося введення в 6-те положення тіазоло[4,5-b]піридин-2-ону фенілазо замісни$к а$, що дало можливість утричі підвищити його протипухлинний потениіал.

Ключові слова: тіазоло[4,5-b]піридини, [3+3] ииклоконденсаиія, структурна модифікаиія, протипухлинна активність.

Т. И. Чабан, Р. Р. Панчук, Е .В. Кленина, Н. Р. Скорохид, В. В. Огуриов, И. Г. Чабан

Синтез и изучение противоопухолевой активности некоторых тиазоло[4,5-b]пиридинов

Резюме

Цель. Синтезировать серию новых производных 3Н-тиазоло[4,5b]пиридин-2-она, модифицируя структуру базового гетероцикла в 3-м и 6-м положениях. Исследовать противоопухолевую активность полученных соединений in vitro на некоторых линиях злокачестенных клеток млекопитаюших. Методы. Органический синтез, ПМР-спектроскопия, определение жизнеспособности клеток окрашиванием трипановым синим. Результаты. Предложен удобный синтетический подход и установлены оптимальные условия для проведения реакиий получения 3Н-тиазоло [4,5-b]пиридин-2-онов. Реакиией [3+3] ичиклоконденсации 4-имино-2-тиазолидона с аиетилацетоном и $\alpha$-фенилазоацетилацетоном в среде метанола в присутствии метилата натрия получены 5,7-диметил-3Н-тиазоло [4,5-b]пиридин-2-он и 6-фенилазо-5, 7-диметил3Н-тиазоло[4,5-b] пиридин-2-он, которые использованы как исходные вещества для будущей структурной модификаиии базового тиазоло[4,5-b]пиридинового гетероцикла в 3-м и 6-м положе- 
ниях. Введением исходных соединений в реакции циианоэтилирования с последующим гидролизом полученного продукта алкилирования, проходящего через стадию выделения соответствующих калийных солей, с дальнейтим гидразинолизом продуктов, а также в реакцию восстановительного расщепления со следующим ацилированием продукто получена серия новых производных $3 \mathrm{H}$ тиазоло[4,5-b]пиридин-2-она. Выводы. Тиазоло[4,5-b]пиридин2-он можна считать перспективным молекулярным каркасом, позволяющим использовать указанную конденсированную систему для рационального дизайна потенциальных лекарственных средств с широким спектром разных видов биологической активности. Наиболее эффективним оказалось введение в 6-е положение тиазоло[4,5-b]пиридин-2-она фенилазо заместителя, что дало возможность втрое повысить его противоопухолевый потенцииал.

Ключевые слова: тиазоло[4,5-b]пиридинь, [3 + 3] ичклоконденсация, структурная модификация, противоопухолевая активность.

\section{REFERENCES}

1. Lesyk R. B., Zimenkovsky B. S. 4-Thiazolidones: centenarian history, current status and perspectives for modern organic and medicinal chemistry // Curr. Org. Chem.-2004.-8, N 16.P. 1547-1577.

2. Saed H. H., Morsy E. M. H., Kotb E. R. Facile novel synthesis and reactions of thiazolidin-4-one derivatives for antimicrobial agents // Synth. Commun.-2010.-40.-P. 2712-2722.

3. Lee Y. R., Dong J. K., Kyung H. Y., Inhee M.-J. Synthesis of thia (oxa)zolopyridines and their inhibitory activities for $\beta$-amyloid fibrillization // Bull. Korean Chem. Soc.-2008.-29, N 12.P. 2331-2336.

4. Rao A. U., Palani A., Chen X., Huang Y., Aslanian R. G., West R. E. Jr., Williams S. M., Wu R. L., Hwa J., Sondey C., Lachowicz $J$. Synthesis and structure-activity relationships of 2-(1,4'-bipiperidin-1'-yl)thiazolopyridine as $\mathrm{H} 3$ receptor antagonists // Bioorg. Med. Chem. Lett.-2009.-19, N 21.-P. 6176-6180.

5. Bebernitz G. R., Beaulieu V., Dale B. A., Deacon R., Duttaroy A., Gao J., Grondine M. S., Gupta R. C., Kakmak M., Kavana M., Kirman L. C., Liang J., Maniara W. M., Munshi S., Nadkarni S. S., Schuster H. F., Stams T., St. Denny I., Taslimi P. M., Vash B., Caplan $S$. L. Investigation of functionally liver selective glucokinase activators for the treatment of type 2 diabetes // J. Med. Chem.-2009.-52, N 19.-P. 6142-6152.

6. Haydon D. J., Bennett J. M., Brown D., Collins I., Galbraith G., Lancett P., Macdonald R., Stokes N. R., Chauhan P. K., Sutariya J. K., Nayal N., Srivastava A., Beanland J., Hall R., Henstock $V$., Noula C., Rockley C., Czaplewski L. Creating an antibacterial with in vivo efficacy: synthesis and characterization of potent inhibitors of the bacterial cell division protein FtsZ with improved pharmaceutical properties // J. Med. Chem.-2010.-53, N 10.-P. 3927-3936.
7. al-Thebeiti M. S. Synthesis of some new thiazolo[3,2-a]pyridines and related heterocyclic systems // IFarmaco.-2000.-55, N 2.-P. 109-118.

8. Kulkarni S. S., Newman A. H. Discovery of heterobicyclic templates for novel metabotropic glutamate receptor subtype 5 antagonists // Bioorg. Med. Chem. Lett.-2007.-17, N 11.-P. 29872991.

9. Lin R., Johnson S. G., Connolly P. J., Wetter S. K., Binnun E., Hughes T. V., Murray W. V., Pandey N. B., Moreno-Mazza S. J., Adams M., Fuentes-Pesquera A. R., Middleton S. A. Synthesis and evaluation of 2,7-diamino-thiazolo[4,5-d] pyrimidine analogues as anti-tumor epidermal growth factor receptor (EGFR) tyrosine kinase inhibitors // Bioorg. Med. Chem. Lett.-2009.-19, N 8.-P. 2333-2337.

10. Komoriya S., Kobayash S., Osanai K., Yoshino T., Nagata T., Haginoya N., Nakamoto Y., Mochizuki A., Nagahara T., Suzuki M., Shimada T., Watanabe K., Isobe Y., Furugoori T. Design, synthesis, and biological activity of novel factor Xa inhibitors: improving metabolic stability by S1 and S4 ligand modification // Bioorg. Med. Chem.-2006.-14, N 5.-P. 1309-1330.

11. Singh B., Bacon E., Lesher G., Robinson S., Pennock P. O., Bode D. C., Pagani E. D., Bentley R. G., Connell M. J., Hamel L. T. Novel and potent adenosine 3',5'-cyclic phosphate phosphodiesterase III inhibitors: thiazolo[4,5- $b][1,6]$ naphthyridin-2-ones // J. Med. Chem.-1995. -38, N 14.-P. 2546-2550.

12. Matysiak J., Karpinska M. M., Niewiadomya A., Wietrzyk J., Klopotowska D. One-pot synthesis of new (1,3-thiazolo[5,4-b] pyridin-2-yl)benzenediols and their antiproliferative activities against human cancer cell lines // Chem. Biodivers.-2012.-9, N 1.-P. 48-57.

13. Sakkiah S., Thangapandian S., John S., Lee K. W. Pharmacophore based virtual screening, molecular docking studies to design potent heat shock protein 90 inhibitors // Eur. J. Med. Chem.2011.-46, N 7.-P. 2937-2947.

14. Biamonte M. A., Van de Water R., Arndt J. W, Scannevin R. H., Perret D., Lee W. C. Heat shock protein 90: inhibitors in clinical trials // J. Med. Chem.-2010.-53, N 1.-P. 3-17.

15. Li $Q ., X u W$. Novel anticancer targets and drug discovery in post genomic age // Curr. Med. Chem. Anticancer Agents.-2005.-5, N 1.-P. 53-63.

16. Grankvist K., Lernmark A., Taljedal I. B. Alloxan cytotoxicity in vitro. Microscope photometric analysis of Trypan Blue uptake by pancreatic islet cells in suspension // Biochem. J.-1977.-162, N 1.-P. 19-24.

17. Chaban T. I., Zimenkovskii B. S., Komaritsa I. D., Chaban I. G. Reaction of 4-iminothiazolidin-2-one with acetylacetone // Russ. J. Org. Chem.-2012.-48, N. 2.-P. 268-272.

18. Panchuk R. R., Chumak V. V., Fil' M. R., Havrylyuk D. Ya., Zimenkovsky B. S., Lesyk R. B., Stoika R. S. Study of molecular mechanisms of proapoptotic action of novel heterocyclic 4-thiazolidone derivatives // Biopolym. Cell.-2012.-28, N 2.-P. 121-128.

Received 12.07.12 